\title{
SUFISM IN THE PERSPECTIVE OF THE QUR'AN AND HADITH
}

\author{
Nurul Azizah \\ Nuza_azizah@unwahas.ac.id \\ Universitas Wahid Hasyim Semarang \\ M. Aris Faisol \\ muhammadarisfaisol064@gmail.com \\ IAIN Salatiga
}

\begin{abstract}
An understanding of the inner element is also called Sufism. It is from the Qur'an and the Sunnah that the Sufis first base their opinions on morals and behavior, longing and love for God, makrifat, suluk (path), as well as spiritual practices. This research is library research that aims to analyze "Sufism in the perspective of the Qur'an and Hadith". The results of this study indicate that Sufism and Sufism have a certain position in the Islamic environment. The main teachings of Sufism when viewed in terms of its basics both from the Qur'an and Hadith, it can be found that Sufism teaches zuhudan to the world and complete surrender only Allah alone and make Him the highest love above all love.
\end{abstract}

Key Word: Sufism, Al-Qur'an, Hadith

\begin{abstract}
Abstrak
Pemahaman terhadap unsur yang bersifat batiniah disebut juga tasawuf. Dari Al-Qur'an dan As Sunnah itulah, para sufi pertama-tama mendasarkan pendapat-pendapat mereka tentang moral dan tingkah laku, kerinduan dan kecintaan pada Ilahi, makrifat, suluk (jalan), dan juga latihan-latihan rohaniah. Penelitian ini merupakan penelitian Library research yang bertujuan untuk menganalisis "Tasawuf dalam perspektif al-Qur'an dan Hadis". Hasil penelitian ini menunjukkan bahwa tasawuf dan sufi memiliki posisi tertentu dalam lingkungan Islam Adapun ajaran utama dari tasawuf jika dilihat dari segi dasar-dasarnya baik dari al-Qur'an maupun hadis, maka dapat ditemukan bahwa tasawuf mengajarkan kezuhudan terhadap dunia dan penyerahan diri sepenuhnya hanya kepada Allah semata dan menjadikanNya kecintaan tertinggi di atas segala cinta.
\end{abstract}

Kata Kunci: Tasawuf, al-Qur'an, Hadis 


\section{INTRODUCTION}

The Qur'an and the Sunnah are texts. Every Muslim anytime and anywhere is burdened with the responsibility to understand and implement its contents in the form of real practice. Understanding the texts without practice will create gaps. In general, Islamic teachings regulate life that is both outward and inward. An understanding of the inner element is also called Sufism. It is from the Qur'an and the Sunnah that the Sufis first base their opinions on morals and behavior, longing and love for God, makrifat, suluk (path), as well as spiritual practices.

Sufism as a discourse, nowadays has attracted great attention from Muslims, including the world of education. For example, the increasing number of books that discuss Sufism in a number of libraries. Sufism in its formation is a manifestation of morality or religion. This religious moral is alluded to in the Qur'an and As-Sunnah. Sufism uses more feelings (dzauq) and psychological training (riyadlah) by increasing the number of acts of worship. To see the basics of Sufism, this journal will discuss the naqli basis of Sufism. The naqli foundation in question is the basis of the Qur'an and hadith. For more details will be described in the discussion of this paper.

\section{DISCUSSION}

\section{A. Definition of Sufism}

Linguistically, the origin of the word Sufism is still debated by researchers in the field of Sufism. Both etymologically and terminology, experts have different opinions about the meaning of Sufism. Etymologically, many opinions have emerged regarding the origin of the word Sufism, including the following: 
1. Shufi (صوفى), from the words shafi (صفافى) and shafa (صفى) which are defined as the names of people who are "clean" or "holy". It means a person who purifies himself before Allah. A Sufi is a person who is purified or has purified himself through exercises and worship, where their goal is to gain maghfirah (forgiveness) and the pleasure of Allah. ${ }^{1}$

2. Al-shaff (صآن), which is a word that is attributed to people who are always in the front row when praying. The reason is that people who pray in the first row get glory and reward from Allah SWT. ${ }^{2}$

3. Ahl Al-Shuffah (أهل الصفّة), namely people who live a lot in the porches of the mosque and devote their lives to worshiping Allah. ${ }^{3}$

4. Shufanah (صوفنة), which is a kind of small, hairy fruit that grows a lot in the deserts of Arabia. This is due to the hairy clothing of the Sufis like the fruit, indicating the simplicity of clothing and food as a form of the nature of zahid and wira'i.

5. Al-shuff (الصوف) which means wool. This is based on the Sufis who always wear clothes of coarse wool and very simple. This woolen cloth is a symbol of simplicity and poverty, yet filled with a noble heart.

6. Another group claims that Sufism comes from the Greek root Sophia. This term is equated in meaning with the word wisdom (حكمة) which means wisdom. This language has entered into Islamic

\footnotetext{
${ }^{1}$ Muhammad Solikhin, Tasawuf Aktual:Menuju Insan Akmil, (Semarang: Pustaka Nuun, 2004), hlm. 5.

${ }^{2}$ Ris'an Rusli, Tasawuf dan Tarekat, (Jakarta: PT RajaGrafindo Persada, 2013), hlm. 6

${ }^{3}$ Rosihon Anwar dan Mukhtar Solihin, Ilmu Tasawuf, (Bandung: CV Pustaka Setia, 2000), hlm. 9.
} 
philosophy and influenced the understanding of the Sufis as people who understand wisdom. ${ }^{4}$

Meanwhile, in terms of terminology, there are many definitions that can be described regarding the meaning of Sufism. The number of definitions that exist is because each person interprets Sufism according to the level or inner experience he experiences.

1. Al-Jurairi argues that Sufism is "Entering all thoughts (morals) that are Sunni and out of low character"5

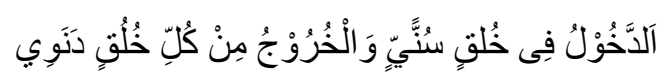

2. The formula given by Al-Junaidi quoted by Cecep Alba in his book "Sufism and the Order" means that Sufism is:

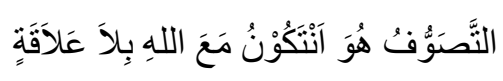

"Sufism is that you are with Allah without 'alaqah (without intermediaries). $" 6$

3. Imam al-Ghazali expressed the opinion of Abu Bakr al-Kattaany who stated:

التصوف خلق قمن زاد عليك بالخلق زاد عليك بالتصوف فالعباد اجابت نفوسهم الى

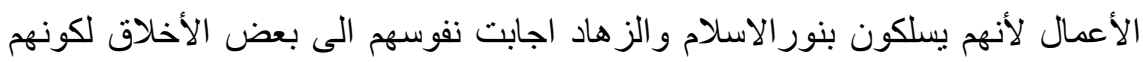

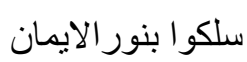

"Sufism is character. Whoever gives character to you means that he provides provision for himself in Sufism. So servants whose souls receive (orders) to do charity, because they actually do suluk with (guidance) Islam. And the zuhud experts whose souls receive

${ }^{4}$ Moenir Nahrowi Tohir, Menjelajahi Eksistensi Tasawuf: Meniti Jalan Menuju Tuhan, (Jakarta: PT. As-Salam Sejahtera, 2012), hlm. 6.

${ }^{5}$ Rosihon Anwar dan Mukhtar Solihin, Ilmu Tasawuf, hlm. 12. 10.

${ }^{6}$ Cecep Alba, Tasawuf dan Tarekat, (Bandung: PT Remaja Rosdakarya, 2012), hlm. 
(orders) to do some (commendable) morals, because they have done suluk with the nur (guidance) of their faith". ${ }^{7}$

4. 4. Al-Junaidi summed up the meaning of Sufism by: Cleansing the heart from what disturbs the feelings of most creatures, extinguishing the qualities of weakness as humans, avoiding all calls from lust, approaching the sacred qualities of spirituality, and relying on the sciences of nature, sowing advice to every human being, holding fast to Allah's commands in terms of nature and following the example of the Prophet in matters of Shari'a. ${ }^{8}$

From the many understandings of Sufism that exist, it can be drawn an understanding that Sufism is self-cleaning that emphasizes the inner and spiritual dimensions. Sufism is an effort to liberate and cleanse oneself from human nature, fight against lust, and live life on the axis of makrifatullah and mahabatullah in order to get closer and achieve His pleasure. ${ }^{9}$

In Sufism, it is known that there are spiritual exercises, which are gradually taken at various levels, with the terms level levels (maqomat) and mental states (ahwal). Maqam is the result of sincerity and continuous struggle, which means a person can only move and rise from a higher state to a higher state after going through training (riyadhah) and instilling better habits. And perfecting the conditions that must be done at the station below it. Examples are taubah, zuhud, wara ', faqr, shabr, ridha, and so on. While it is a condition of the soul that is obtained by a person without going through training, but is

\footnotetext{
${ }^{7}$ Mahjuddin, Kuliah Akhlak Tasawuf, (Jakarta: Kalam Mulia, 1991), hlm. 47.

${ }^{8}$ Rosihon Anwar dan Mukhtar Solihin, Ilmu Tasawuf, hlm. 13-14.

${ }^{9}$ Muhammad Fethullah Gullen, Tasawuf untuk Kita Semua, (Jakarta: Republika, 2014), hlm.. 6.
} 
solely a gift from Allah SWT. To someone he wants. Examples include qurb, hubb, peaceful, sure, witnessing (musyahadah) and so on. Both of them have a normative basis from Islam. ${ }^{10}$

\section{B. Sufism in the Perspective of the Qur'an}

The Qur'an is the book of Allah which contains contents of Islamic teachings, both creed, shari'ah and mu'amalah. These three charges are widely reflected in the verses contained in the Qur'an. On the one hand, there are verses from the Qur'an that need to be understood contextually-spiritually. If only understood outwardly, the verses of the Qur'an will feel stiff, less dynamic, and it is not impossible to find problems that are psychologically unacceptable. ${ }^{11}$

\section{The Call of the Qur'an to Be Zuhud}

It is well known that the Sufis tend to behave zuhud, and if you look at the attitude of zuhud towards the world and warn of drowning in the various pleasures of life, many are called for in the Qur'an. One of the verses that is clear and strongly argued is Allah's description of the world as something that is rapidly changing and disappearing. (al-Hadid (57): 20). ${ }^{12}$

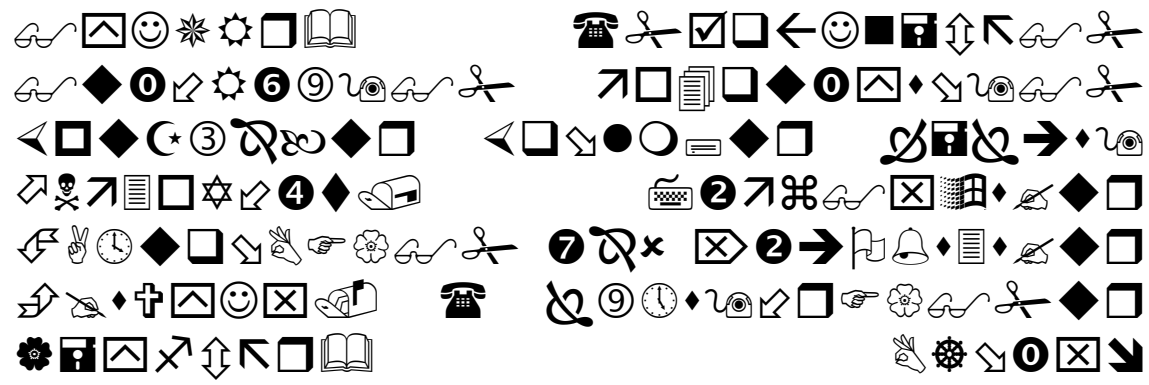

\footnotetext{
${ }^{10}$ M. Amin syukur, Pengantar Studi Islam, (Semarang: Pustaka Nun, 2010), hlm. 156

${ }^{11}$ Rosihon Anwar dan Mukhtar Solihin, Ilmu Tasawuf, hlm. 16.

${ }^{12}$ Kementerian Agama RI, al-Qur'an Tajwid dan Terjemahannya, (Jakarta:
} SYGMA, 2010), hlm. 540. 


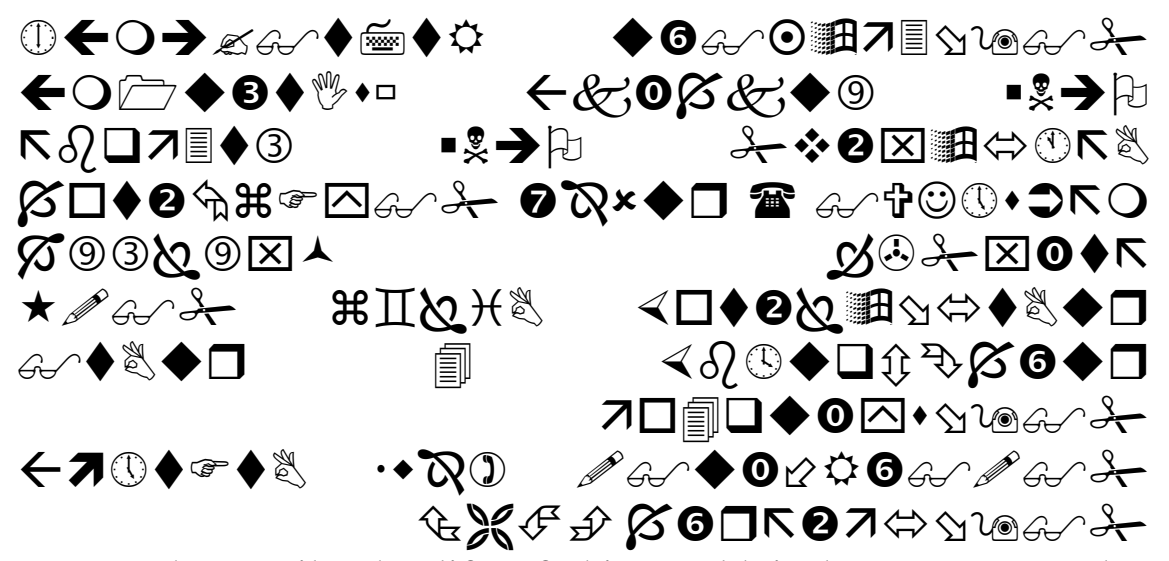

"Know that verily the life of this world is but a game and a distraction, adornment and boasting among you and boasting about wealth and children, like rain whose crops amaze the Farmers; then the plant dries up and you. See it's yellow then crumble. and in the hereafter (later) there is a severe punishment and forgiveness from Allah and His pleasure. and the life of this world is nothing but deceptive pleasure."

In Ibn Kathir's interpretation it is explained that Allah SWT said in a tone of contempt for the life of the world, "that the world is actually just a game and something that neglects to boast about wealth and children. This means that the world is just a pseudo pleasure which if chosen means that he has been deceived by his charm to believe that there is no life after that. ${ }^{13}$

If indeed the world has a status as illustrated in the verse above, it is not eternal and its beauty is only pseudo, then the hearts of the believers should not be captivated and fond of it so that they neglect and turn them away from various kinds of worship and obedience that can bring them closer. to Allah. ${ }^{14}$

\section{The call of the Qur'an to worship} hlm. 2001

${ }^{13}$ Muhammad Nasib ar-Rifa'I, Tafsir Ibnu Katsir, (Riyadh, Gema Insani Press), hlm. 28.

${ }^{14}$ Muhammad Fauqi Hajjaj, Tasawuf Islam dan Akhlak, (Jakarta: Amzah, 2011), 
Sufis are very fond of getting closer to Allah with extra worship. This is in accordance with the word of God, including in Q.S Adzariyat (51): $56^{15}$

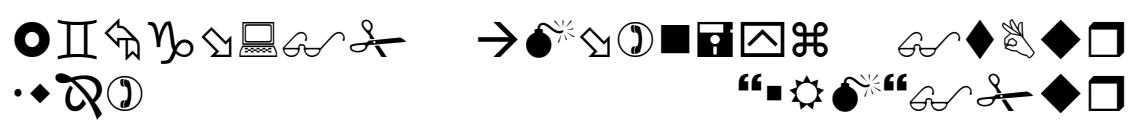

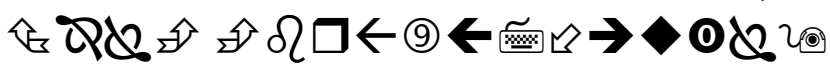

"And I did not create the jinn and mankind except that they might serve Me."

Interpreting this verse, Ibn Kathir states: "That is, I created them to worship Me because of My need for them. According to Ibn Abbas, it means except that they acknowledge their servitude to $\mathrm{Me}$, either voluntarily or forced. This interpretation was chosen by Ibn Jarir (ath-Tabari). Meanwhile, Ibn Juraih interprets it as "except so that they know Me". While ar-Rabi 'bin Anas interpreted it as "except for worship"

The purpose of Sufism in general is to get closer to God, but in particular, Sufism has two goals, namely: fostering moral and ma'rifatullah aspects through direct disclosure or the kaysf al-hijab method, and discussing how the system of self-recognition and approach to God is philosophical mystique. ${ }^{16}$

\section{Appreciation of the Qur'an to Ilham}

One of the verses related to inspiration is Q.S al-Ankabut (29): 69 which explains that mujahadah against lust is the way to achieve guidance.

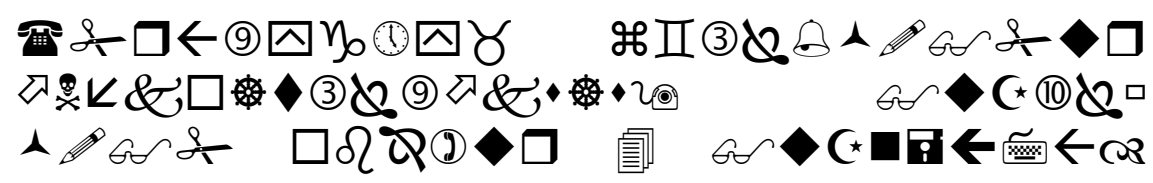

${ }^{15}$ Kementerian Agama RI, al-Qur'an Tajwid dan Terjemahannya, hlm. 523

${ }^{16}$ A Rivay Siregar, Tasawuf dari Sufisme klasik ke neo-sufisme, (Jakarta: PT Raja Grafindo Persada, 2002), hlm. 57. 


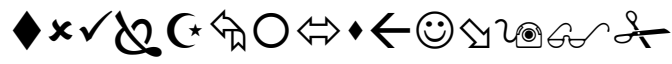

"And those who strive for (seeking our pleasure), we will indeed show them our ways. and verily Allah is with those who do good."

In interpreting this verse, Ibn Kathir explains that Allah SWT guarantees guidance for everyone who strives for jihad by following the Prophet. The way to achieve inspiration is to hold back one's passions and cleanse oneself from despicable morals until it reaches the emptying of the heart from other than Allah and filling it with dhikrullah. ${ }^{18}$

Among the verses of the Qur'an that provide evidence for Sufism are as follows:

The arguments of the Qur'an are recommended for Sufism

\begin{tabular}{|l|l|}
\hline \multicolumn{1}{|c|}{ Surat/Ayat } & \multicolumn{1}{c|}{ Content } \\
\hline Al-Syams/08 & Human nature is good and evil \\
\hline Al-Syams/09 & Good nature will be happy \\
\hline Yusuf/53 & Lust that commands evil \\
\hline 'Abasa/40-41 & People who fear Allah \\
\hline Al-Fathir/05 & The world's life is beguiling \\
\hline Al-Hadid/20 & The life of the world is a game \\
\hline Al-Baqarah/112 & Obedient people are rewarded \\
\hline An-Nisa'/77 & The pleasures of this world are only temporary \\
\hline Al-Fajr/27,28,30 & Calm heart and soul \\
\hline Al-Ma'idah/54 & People who love Allah \\
\hline Al-Baqarah/282 & Have faith in Allah \\
\hline Al-Kahfi/65 & People who are given grace and knowledge \\
\hline
\end{tabular}

${ }^{17}$ Kementerian Agama RI, al-Qur'an Tajwid dan Terjemahannya, 404.

${ }^{18}$ Muhammad Nasib ar-Rifa'I, Tafsir Ibnu Katsir, hlm. 422. 


\begin{tabular}{|l|l|}
\hline An-Najm/11-12 & Knowledge gained from the heart \\
\hline At-Takwir/22-23 & Knowledge gained from the heart \\
\hline Al-Qaff/16 & Humans who are very close to Allah \\
\hline Al-Baqarah/115 & Humans who are very close to Allah \\
\hline Al-Maidah/54 & Man and God love each other \\
\hline Al-Tahrim/08 & Humans to always repent \\
\hline An-Nur/35 & Allah gives light to what he wants \\
\hline Al-Baqarah/186 & Allah's closeness to His servants \\
\hline Al-Hujurat/13 & The level of piety \\
\hline At-Thalaq/03 & Tawakkal level \\
\hline Ibrahim/07 & Gratitude level \\
\hline Al-Mu'minun/55 & Level of patience \\
\hline Al-Ma'idah/119 & Level of pleasure \\
\hline
\end{tabular}

\section{Sufism in Hadith Perspective}

In line with what is mentioned in the Qur'an, Sufism can also be seen in the context of hadith. In the hadith, there are many statements that talk about the spiritual life of humans. The following are some of the hadiths that can be understood with a Sufism approach.

$$
\text { من عرف نفسه فقد عرف ربّه }
$$

"Whoever knows himself knows his Lord"

$$
\text { كنت كنز ا مخفيا فأحببت أ أعرف فخلقت الخلق فبه عرفوني }
$$

"I am a hidden treasury so I made creatures so that they may know Me."

لايزال العبد يتقرب الي بالنو افل حتي أحبه فإذا أحبيته كنت سمعه الذي يسمع وبصره الذي ييصربه ولسانه الذي ينطق به ويده الذي يبطش بها ورجله الذي

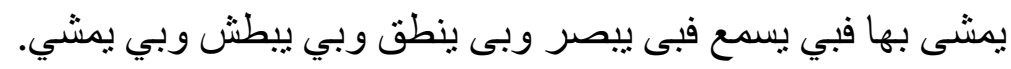


"Always a servant draws near to Me with sunnah practices so that I love him. So when he loves her, I will be his listener with which he sees and his tongue with which he speaks and his hands with which he wipes and his feet with which he tries, then with Me he hears, sees, speaks, speaks, thinks, review and walk."

The above hadith gives an indication that man and God can unite. The human self can be dissolved in God, hereinafter known as fana', namely the mortal nature of creatures as those who love God as they love. ${ }^{19}$

In the life of the Prophet Muhammad, there are also clues that describe him as a Sufi. The Prophet Muhammad had exiled himself to the Cave of Hira ahead of the revelation. He secluded himself, temporarily cut off his relations with the surrounding community, sought spiritual cleanliness and asked for the provisions of the path to be taken in each month of Ramadan. It was there that he released his soul from the bonds of worldly luxury. He brought some provisions, and the rest of his attention was directed to the nature of the universe. Contemplating and looking at the eyes of the heart to all the former powers and deeds of God. ${ }^{20}$

The life of the Prophet Muhammad and the history of his struggle for 23 years, is a very important source of role model for all his people. He can be seen from all aspects of life. His honesty in commerce, his sincerity and firmness in holding orders, his compassion in war, his wisdom in governing the country and his ability to make speeches and other virtues.

\section{The humility of the Prophet and its simplicity}

\footnotetext{
${ }^{19}$ Rosihon Anwar dan Mukhtar Solihin, Ilmu Tasawuf, hlm. 26.

${ }^{20}$ Hamka, Tasawuf Perkembangan dan Pemurniannya, (Jakarta: Pustaka Panjimas, 1993), hlm. 20.
} 
If you look at the sirah of the Prophet Muhammad, it will be clearly exposed that there is a close relationship between the Prophet's lifestyle which is full of zuhudan and simplicity. One example of his zuhudan is when he eats.

One hadith that shows his simplicity in eating is narrated by Abu Hazim from the Messenger of Allah that he is very modest in eating. He narrated: I saw Abu Hurairah gesturing with his finger several times, saying: "By the One in whose hand the soul of Abu Hurairah is, the Messenger of Allah was never full for three days in a row by eating wheat bread until he died." (H.R al-Bukhari). ${ }^{21}$

\section{Extra Worship of the Prophet}

If you look closely at the life of the Prophet, it is clear that he drew closer to Allah by means of extra worship and this became a source of inspiration for the early generations of zuhud. An example of his extra worship is that he likes to pray in the middle of the night. In addition to prayer, he also likes to do sunnah fasting, among the sunnah fasting that he likes is fasting the month of Sha'ban. ${ }^{22}$

The Sufis who yearn for glory really yearn to live like the Prophet, both in the community and individually, for example by imitating his attitude and behavior, his wise words. With their obedience to Allah's commands and prohibitions, the Sufis themselves will get the signs of Allah that Allah has bestowed on them, through stages or stations and then matters related to him. ${ }^{23}$

${ }^{21}$ Muhammad Fauqi Hajjaj, Tasawuf Islam dan Akhlak, hlm. 53.

${ }^{22}$ Muhammad Fauqi Hajjaj, Tasawuf Islam dan Akhlak, hlm. 59.

${ }^{23}$ Moenir Nahrowi Tohir, Menjelajahi Eksistensi Tasawuf, (Jakarta: PT As-Salam Sejahtera, 2012), hlm. 7. 


\section{The Prophet's Appreciation of Ilham}

Inspiration is the goal of Sufism. Ilham means the direction of Allah SWT towards the people he wants in speech and action. This is in accordance with the hadith below:

\section{إن من العلم كهيئة المكنون لايعلمه إلاالعلما ء با لله فإذا نطقوا به لاينكره إلا أهل الغرة

"Indeed there is knowledge whose status is like a hidden gem (almaknun) which is not only known to those who know Allah. And if they say it, no one will deny it except those who are deceived by Allah."

Islam recommends tadabbur and tafakkur contemplating Allah's creation by encouraging rational observation activities within the limits of human ability which can further strengthen the faith of Allah in the heart.

\section{CONCLUSION}

Sufism is self-purification that emphasizes the inner and spiritual dimensions. Sufism is an effort to liberate and cleanse oneself from human nature, fight against lust, and live life. The purpose of Sufism in general is to get closer to God, but in particular, Sufism has two goals, namely: fostering moral aspects and ma'rifatulla

Sufism when viewed from the basics of the Qur'an and hadith, it can be understood that Sufism and Sufi have a certain position in the Islamic environment. it can be found that Sufism teaches zuhudan to the world and complete surrender to Allah alone and makes Him the highest love above all love. The spiritual values expressed and implied in the Qur'an and hadith are the main arguments for the existence of Sufism in the universe of Allah. 


\section{DAFTAR PUSTAKA}

Alba, Cecep, Tasawuf dan Tarekat, Bandung: PT Remaja Rosdakarya, 2012.

Anwar, Rosihon dan Mukhtar Solihin, Ilmu Tasawuf, Bandung: CV Pustaka Setia, 2000.

ar-Rifa'i, Muhammad Nasib, Tafsir Ibnu Katsir, Riyadh, Gema Insani Press, 2010.

Gullen, Muhammad Fethullah, Tasawuf untuk Kita Semua, Jakarta: Republika, 2014.

Hajjaj, Muhammad Fauqi, Tasawuf Islam dan Akhlak, Jakarta: Amzah, 2011.

Hamka, Tasawuf Perkembangan dan Pemurniannya, Jakarta: Pustaka Panjimas, 1993.

Kementerian Agama RI, al-Qur'an Tajwid dan Terjemahannya, Jakarta: SYGMA, 2010.

Mahjuddin, Kuliah Akhlak Tasawuf, Jakarta: Kalam Mulia, 1991.

Rusli, Ris'an, Tasawuf dan Tarekat, Jakarta: PT RajaGrafindo Persada, 2013.

Siregar, A Rivay, Tasawuf dari Sufisme klasik ke neo-sufisme, Jakarta: PT Raja Grafindo Persada, 2002.

Solikhin, Muhammad, Tasawuf Aktual: Menuju Insan Akmil, Semarang: Pustaka Nuun, 2004.

Syukur, M. Amin, Pengantar Studi Islam, Semarang: Pustaka Nun, 2010.

Tohir, Moenir Nahrowi, Menjelajahi Eksistensi Tasawuf: Meniti Jalan Menuju Tuhan, Jakarta: PT. As-Salam Sejahtera, 2012. 